\title{
Shoring Up the 'Home Guard'? Reflections on the Development and Deployment of Police Support Volunteer (PSV) Programmes in England and Wales
}

\section{Introduction}

\section{Background}

Referring to the assortment of providers of policing services - from the public police to private security guards to the actions of citizens and communities - there is an extensive literature on the 'pluralization' of policing (Bayley and Shearing, 1996; Loader, 2000; Crawford and Lister, 2004a,b; Crawford, 2008a,b; Stenning, 2000; 2009; Crawford, 2013). Indeed, the movement towards pluralisation, both internal and external to the public police, 'amount to the restructuring of policing in contemporary democratic societies' (Bayley and Shearing, 1996: 585). Whilst the role of civil society within this restructuring is generally acknowledged, the spotlight of empirical inquiry tends to shine on the privatization of functions traditionally conducted by the public police, on the visible face of policing and on the array of patrol and guarding agents employed in spheres wider than the public police (Crawford, 2008a; 2013). Yet pluralisation goes further than this, often with little scrutiny (Crawford, 2008a). This article, focusing on the role of volunteers within the extended police family, starts to fill this empirical lacuna.

\section{Volunteers and the police service}

Volunteers - citizens who give time freely to benefit another person, group or cause (Wilson, 2000: 215) - have long played a role in crime control. The informal mechanisms of social control, comprising the voluntary actions, habits and behaviours of ordinary citizens rather than those of paid agents of the state, characterised policing before the establishment of the New Police in 1829 (Reiner, 2000). Whilst the actions of salaried police constables came to displace those of volunteers (Crawford, 1999; Emsley, 2011), they did not entirely supersede them. For example, Special Constabularies - which comprise uniformed volunteer constables with full police powers (see Seth, 1961; Leon, 1991; Mirrlees-Black and Bryon, 1994; Gaston and Alexander, 2001; Whittle, 2014; Bullock, 2014; Bullock and Leeney, 2014) - have been formally allied to regular constabularies since the mid- $19^{\text {th }}$ century. The special constable was traditionally retained by constabularies as a 'reserve' to be deployed in times of emergency (Seth, 1961; Leon, 1991; Mirrlees-Black and Bryon, 1994) and today supplements and reinforces day-to-day police work in wide-ranging ways (Whittle, 2014; Bullock and Leeney, 
2014). More generally, citizens have been implored to take responsibility for their own security and that of their neighbourhoods and encouraged to work proactively with constabularies to resolve problems at the local level in contemporary times (Garland, 1996; Crawford, 1999; Bullock, 2014). Neighbourhood Watch - groups of citizens who band together and act as the 'eyes and ears' of the police - well embodies these practices (Rosenbaum, 1987; Laycock and Tilley, 1995; Bullock, 2014) as does community policing which calls for citizens to work proactively with constabularies to identify and resolve problems within neighbourhoods (Trojanowicz and Bucqueroux, 1990; Bullock, 2014). Whilst different in emphasis, these forms of volunteering are now well established, the focus of this article - the Police Support Volunteer (henceforth PSV) - is somewhat different.

\section{The Police Support Volunteer (PSV)}

PSV programmes have been evident in England and Wales since the early 1990s. It seems that many early PSVs were public spirited citizens who spontaneously volunteered their time to staff public receptions in police stations that had been threatened with closure (Unison, 2014). Associated with enthusiastic advocates, programmes have developed with little central or strategic oversight (Bullock, 2014). However, the Home Office started to promote PSV programmes in the early 2000s (Unison, 2014) and PSVs featured in government reports published in the decade that followed (e.g. Home Office, 2004; NPIA, 2008; Neuberger, 2009).

PSVs might be best characterised as 'auxiliaries' who support the functions of constabularies in ways that we will soon explore in detail. For the time being it suffices to say that PSVs have characteristics in common with other agents operating within constabularies but they are also distinctive. As they give their time for free, they resemble the aforementioned special constable. However, they are not sworn officers and they do not sport police powers. Nonuniformed PSVs support the administration of constabularies and so resemble 'civilian' police staff whereas uniformed PSVs provide a visible police presence and so resemble Police Community Support officers (PCSOs). However, as volunteers they are of course unpaid.

PSVs are a marginal but growing branch of the extended police family. Unison (2014) reported that there were 9,000 PSVs in January 2014. By comparison there were some 130,000 officers in the 43 geographical constabularies in England and Wales, 65,000 police 
staff, 14,000 PCSOs and 18,000 special constables at this time (ONS, 2013). Given that fewer than 4,000 PSVs were retained by constabularies in 2006 (Wilkins, 2008), their number has increased quickly. Whilst there is variety in respect to the numbers of PSVs retained by constabularies - Unison (2014) reported that Kent Constabulary had appointed 850 PSVs whereas Derbyshire Constabulary had secured just 15 - most constabularies intend to increase the number of PSVs (HMIC, 2013; Unison, 2014). As such it would seem to be timely to consider the ways that PSVs have been supporting constabularies, the ways that they are supported and managed and the extent to which they are integrated. Before we do, let us consider the rationale for the development of PSV programmes evident within official discourses.

\section{The rationale for Police Support Volunteer (PSV) programmes}

The proliferation of PSVs in contemporary constabularies should be understood as an outcome of dominant political ideologies which have called for a recalibration of the relationship between the state and the citizen and, more prosaically, economic pressures. Let us consider these in turn.

First, powerful neo-liberal critiques have displaced the notion that paid state agents should be primary providers of security (Rose and Miller 1992; Garland 1996; O’Malley and Palmer 1996); blending neo-liberalism and neo-communitarianism, calls to rebalance citizen rights against communal responsibilities have come to the fore (Giddens, 1998; Etzioni, 1995); and, strains of political thought which foreground the mobilisation of citizens to reinvigorate democratic structures have (re)emerged and become influential (Putnam, 2000). Indeed, PSV programmes developed within the context of the discourses of successive administrations from across the political spectrum - which drew on the language of 'rights' and 'responsibilities,' 'self-policing' and 'active citizenship' (Home Office, 2004; Neuberger, 2009; Cabinet Office, 2010; Conservative Party, 2010). For New Labour, effective policing at the local level entailed 'moving from traditional notions of policing simply by consent or people's passive acquiescence, to policing with the proactive engagement and co-operation of communities' (Home Office, 2004: 20). At the heart of the discourse of the Conservative-led coalition government was a commitment to the redistribution of power from the central state to communities and citizens. This language - sometimes referred to in Conservative Party discourse as the 'Big Society' - calls for 'a radical redistribution of power away from Westminster and Whitehall to councils, communities and homes across the nation' (Cabinet 
Office, 2010: 7). Calling for a 'new national energy and commitment to social action' (Conservative Party, 2010:1), rebuilding civic society has a central place in such discourse.

Second, PSVs bolster the strength of constabularies and have been viewed as a cost-effective way of increasing capacity. Gravelle and Rogers (2009: 59) argue that 'using volunteers could potentially save hundreds of thousands of pounds a year for the police service' and that 'the possible economic savings are considerable, without allowing for the other diverse advantages attached to their use'. Although not all constabularies keep records of the hours given by PSVs, data obtained by Unison (2014) indicate that they can be considerable. For example, in 2013 PSVs gave Thames Valley Police 70,459 hours, West Yorkshire Police 19,432 hours and Norfolk Constabulary 18,999 hours (Unison, 2014). It should be stressed that operating volunteer programmes is not free or even a cost neutral exercise. It is widely recognised that volunteer programmes need to be well resourced and effectively managed if they are to meet proffered outcomes (Brudney, 1999; Wilson and Pimm, 1996; Neuberger, 2009), points which are returned to throughout this article. At the very least PSV programmes generate costs from advertising for and recruiting volunteers, providing induction and training, paying out-of-pocket expenses, hosting volunteer events (such as award ceremonies), overheads (such as access to Information Communication and Technology, desk space and support from Human Resources) and - perhaps most importantly - from their dayto-day coordination, supervision and management. The true cost of deploying PSVs is unknown as many constabularies do not keep information and, since Norfolk Constabulary estimated the cost of operating their PSV programme in 2013 at $£ 229,714$ and Cambridgeshire Police at $£ 0$, there is a lack of consistent monitoring of costs (Unison, 2014). Come what may, equating volunteers and costs, and specifically equating volunteers with cost savings, is controversial, another theme we return to throughout this article.

\section{Methodological approach}

This article is informed by the findings of small-scale empirical study of the experiences of volunteers and those who work with them in one English constabulary. This constabulary has been operating a PSV programme since the mid-1990s and had in the order of 120 PSVs on the books at the time of writing. Data obtained by Unison indicate that this constabulary is in the 'top ten' in respect to the number of hours given by PSVs as a group and as individuals and the amount the force spends operating its PSV programme - indicating a buoyant programme. Within this constabulary PSVs conduct roles in fields as diverse as community 
engagement, cooperate communications, custody, emergency planning, customer service, events and licensing, vehicle maintenance, occupational health and victim support (Unison, 2014). Indeed, the PSVs who participated in this study had or were conducting activities as diverse as valeting cars, managing data and conducting research, operating various watch schemes (Neighbourhood Watch, Farm Watch), staffing front counters, conducting victim satisfaction questionnaires, monitoring Automatic Number Plate Recognition (ANPR) systems, conducting filing and administration for different parts of the organisation (including the prosecution of criminal suspects) and representing (in uniform) constabularies at community and other outreach events, more detail on which shortly.

Twenty qualitative interviews were conducted by the author between June and October 2013. Fourteen were PSVs and the remainder a mixture of police officers and other salaried staff who had experience of managing volunteers. Drawing on the principles of 'key informant' sampling (Parsons, 2008) participants were selected because of their knowledge and experience of working with volunteers and volunteering within this constabulary and beyond. Thus interviewees included members of the coordinating team, managers who had extensive experience of working with volunteers and volunteers who themselves had sustained service. Some interviewees held national positions as a result of their experience in the field. The point of sampling in this way was that interviewees could draw on their own experiences, attitudes and perspectives but also comment more broadly on the position of the volunteer within the service - and indeed nationally - by virtue of their familiarity with PSV programmes. To distinguish between the groups in reporting the results PSVs are referred to as 'volunteers' and all others as 'managers'. To protect the anonymity of some of the participants, certain details have been obscured.

It should be acknowledged at this early stage that the study is small scale and this might well function to limit what can be extrapolated to other constabularies and to limit what can be said with certainty. That said, as has been stressed the participants in the study were 'experts' which gives their observations some authority. In addition, efforts have also been made to link their observations with those of others who have written about the deployment of volunteers in the public sector in order to give the article greater depth. Either way a primary point of the article is to provide material about the development and operation of PSV programmes and to provoke questions about their deployment. This is an under researched area and it is hoped that this article will act as a spring board for further empirical 
interrogation. The following sections consider findings in respect to three themes: the nature of the roles that PSVs play and how these relate to roles played by other actors in the organisation; the coordination, training and supervision of PSVs; the degree to which PSVs are integrated into the organisation, accepted by other actors who work therein and the reasons why the promulgation of PSVs might be resisted by salaried staff. In the discussion, the implications for coordination, integration and effectiveness of policing and for regulation and accountability, themes which have long interested scholars of the pluralisation of policing, are considered.

\section{The position of Police Support Volunteers (PSVs) within contemporary constabularies}

\section{The contours of the PSV role}

A great deal of policing scholarship has been given over to examination of what the police do. Given their novelty, let's start by examining the roles that PSVs conduct and how these relate to those conducted by other actors within the organization. Whilst they may be a relatively new addition to the extended police family, it is clear that PSVs are playing wide ranging roles. Research published by Unison (2014) documents the range of roles conducted by PSVs across England and Wales. PSVs manage Neighbourhood Watch programmes, administer community consultation processes and distribute crime prevention advice. They enter data, conduct research and manage information. Volunteers deliver education programmes in schools and youth groups, compose and edit in-house newsletters and coordinate the activities of other volunteers. In some constabularies, volunteers greet visitors in reception, prepare and serve refreshments in restaurants and bars and act as museum coordinators. Volunteers help and assist with the grooming and training of horses, drive police vehicles between workshops and police stations and they dispatch animals into operational settings. In yet other sets of circumstances volunteers operate closed circuit television (CCTV) and Automatic Number Plate Recognition systems (ANPR). PSVs can be found providing administrative support in all areas of constabularies including offender management and major enquiry teams. In respect to the latter, in some constabularies volunteers are used to monitor CCTV images, review cold case evidence, leaflet and conduct administration on behalf of detectives. Volunteers assist forensics departments by carrying out fingerprint techniques, repackaging exhibits after testing, updating databases and assisting senior technicians. In some constabularies volunteers attend minor scenes of crimes, on a call 
out rota, to provide reassurance to victims, undertake crime scene examinations and provide crime prevention advice.

Given the wide ranging nature of the PSV role, it is pertinent to ask how these relate to roles played by officers and other actors in the organisation. National guidance has stressed that volunteers should complement, rather than replace or displace, the activities of police officers and staff; should help 'free up' salaried staff to perform key operational duties; and, should 'add value' by undertaking activities that police officers and staff would not ordinarily have the capacity to do (NPIA, 2008; Gravelle and Rogers, 2009; Unison, 2014). More specifically, guidance indicates that PSVs should perform 'back office' tasks which 'free' officers to focus on the 'front line' (NPIA, 2008; Gravelle and Rogers, 2009; Unison, 2014). Reflecting these official guidelines participants in this study tended to draw a distinction between the 'front line' and the 'back office' when considering the roles that were suitable for PSVs or otherwise and how the PSV fitted in to the organization. The implication - more or less explicit within the interview data - is that 'back office roles' are suitable for PSVs whereas 'front line' ones are not. To demonstrate, reflecting on her role providing administration for one area of the organization one PSV noted that doing so enabled regular officers to 'get on and fight crime: that is what they are supposed to do' (volunteer 1). Another, who conducted data analysis on behalf of specialist unit, noted that 'by me taking it over it means they can go out on the road rather sit at a desk all day, its freed officers to go out on the road' (volunteer 2).

Given that the notion of a policing 'front line' is ambiguous and contested a distinction between 'front line' and 'back office' policing is disingenuous at the point of principle. As Manning (2013: 26) put it, "like the army, there is a necessary ratio of office staff to " front line'" that is essential in order to keep records, deal with the public in situations, manage human resources, make and keep budgets and carry out legal and scientific analyses'. It is also disingenuous at the point of practice. Providing a uniformed presence within communities, collating intelligence to support proactive and reactive investigations and providing administration to support the prosecution of criminal suspects, it is quite clear that PSVs are conducting roles that go well to the heart of what is conventionally understood as 'front line' policing. Taking even a narrow view of the 'front line', PSVs form part of it. The ambiguous distinction between the 'front line' and the 'back office' is to all intents and purposes irrelevant. 
Conducting 'back office' functions such as administration, filing and staffing receptions, the roles performed by many PSVs resemble those performed by non-uniformed police staff. Referring to the temporary workers, generally provided by an agency, who provide short term cover for permanent members of staff when they are unavailable due say to holiday or maternity leave, one participant characterised some PSVs as 'Free Temps':

A free temp. You only have to look at the job descriptions. This is clearly what they are. Yes, they are free temps (volunteer 3).

Whilst guidelines issued by the Home Office and the College of Policing (Unison, 2014) state that PSVs should not replace salaried staff, concerns have been raised that PSVs are now being used in this way (Gravelle and Roberts, 2009; Unison, 2014). In drawing attention to the sheer range of roles performed by PSVs Unison (2014: 4) argue that volunteering 'spills over into areas that were previously the preserve of directly employed, highly trained, vetted and skilled police employees'. To illustrate, reflecting on the administrative tasks that one PSV participating in the present study stated 'it could quite easily be a part-time civilian job' (volunteer 4). Certainly within this constabulary the deployment of volunteers is viewed as a pragmatic response to the economic reality and it accepted that PSVs sustain and support functions that the constabulary would otherwise be unable to provide due to budget cuts. One manager, who deployed large numbers of PSVs into administrative roles noted:

It's all about cut backs, isn't it? Cut backs, losing money, losing budgets. They have got no admin staff. The fact that we have volunteers in to help, oh! It just makes it so much easier (manager 1)

It is perhaps not surprising that the risk that they would be resented for appearing to occupy the roles of salaried staff who had been made redundant was a primary theme within the accounts of PSVs, a theme to which we turn shortly.

On the face of it, the roles performed by PSVs might best resemble the administrative roles conducted by non-uniformed police staff. However, PSVs also conduct tasks that resemble those of uniformed officers and staff. In this constabulary many PSVs who directly engage with citizens wear a uniform. Uniformed PSVs play a wide range of roles on behalf of this 
constabulary. They attend community events, such as fetes and fairs, chat to citizens with the aim of exchanging information, raising awareness and providing reassurance. They go into schools and youth clubs and speak to young people about the role of the police and give presentations on safety. They attend Neighbourhood Watch meetings on behalf of constabularies providing updates for members and issuing crime prevention advice. They conduct property marking in a wide range of settings including in the homes and businesses of citizens. They deliver newsletters and leaflets. These roles are similar to those conducted by actors within Neighbourhood Policing teams which, reflecting the rhetoric of community policing, seek to raise visibility, promote reassurance and engender interaction with citizens. Most clearly, they are similar roles to those performed by PSCOs. PCSOs provide visible, onfoot patrol in local communities and otherwise aim to reduce demands made of police officers by completing tasks that do not require the powers of sworn officers (O'Neill, 2014a). Indeed, so similar are the functions provided by uniformed PSVs and other uniformed policing teams that 'blue-on-blue' situations - where Neighbourhood Policing teams attended the same community events independently of the teams of PSV - were reported. At the time of writing, the coordination of PSVs and Neighbourhood Policing teams is being formalised within this constabulary at least. It seems quite possible that uniformed PSVs will be assimilated into Neighbourhood Policing teams, something which may come to signify a further development in the evolution of forms of visible patrol and reassurance policing within Anglo-Welsh policing.

In the context of this blurring there is risk that citizens and other actors within the police family will be confused about the PSV role. Citizens are sometimes confused about the roles and responsibilities of PSVs. Something especially apparent where PSVs were in uniform. The uniform is reportedly important for PSVs who interact face-to-face with citizens to promote credibility and professionalism. One noted 'if they are trying to promote the police, wearing the uniform gives increased credibility (volunteer 11) and another 'this is a professional organization, if we are interacting with the public we need to look professional' (volunteer 1). Uniformed PSVs were drawing attention to the 'symbolic power' (Loader, 1997) embodied by the police uniform that marks them as part of the police family and commands respect. However, it can also function to muddle their status. Reflecting research which has demonstrated that citizens are not always able to distinguish between the actors in the extended police family and express confusion regarding the various roles and the powers available to them (Crawford, 2008b; Rowland and Coupe, 2014), participants in this study 
indicated that citizens make little distinction between uniformed PSVs and other uniformed actors in the organisation. In the absence of clarity over the responsibilities and limitations of the PCSO role, Crawford (2008b: 155) noted that 'the public are often left to assume that they can act like police constables'. He went on to explain that on the one hand this may furnish PCSOs with a reassurance premium but on the other hand may give false expectations regarding what they can legitimately achieve (Crawford, 2008b). These themes were certainly present in the accounts of PSVs who participated in the present study. Agreeing that 'to all intents and purposes we look like police officers' one volunteer, whose role was to property mark as part of a Neighbourhood Watch scheme, noted that:

If they want real advice, if they have a real problem well I am not qualified to give them that advice. That would be tricky, it would. So I am always keen to say that proper officers should go and do that side of it. Even though I say 'look I am a volunteer' the minute they see the uniform they forget that. In terms of actual ability to give advice, other than common sense advice, I can't give any (Volunteer 7)

This muddling raises questions about how PSVs, less experienced and less well trained than salaried staff, deal with such requests for assistance. As the quote above indicates PSVs tended to stress that they would give 'common sense' advice if the matter was straightforward or refer them to salaried staff if the matter were more complex. Whilst this might seem fairly intuitive it should not be assumed that referrals will happen. As we will soon examine in more detail many PSVs work away from the direct gaze of salaried staff in the organisation, something which can render it difficult for PSVs to follow up queries raised by citizens. This extract illustrates the potential problems that can occur when PSVs are removed from other actors in the organisation:

I believe it is organized now, but I did find that there was just no one to refer any questions to. Things that needed following up, like people wanting their property back that had been taken for evidence. There was no one to go to. No one at all to ask to follow these queries up. I didn't know quite what to do with them. I wanted them followed up as otherwise it made the police look bad. So that first year wasn't really terribly successful. It wasn't particularly a pleasant experience for me and I felt that as a volunteer I didn't want to be doing something that had adverse repercussions for 
me. I know that sounds awful. But you want the feeling that you are helping someone and are contributing not the feeling that you had let someone down (volunteer 7)

The status of the PSV can also be confusing for other actors within the organisation. Some express surprise when confronted by PSVs. One volunteer, explaining her role conducting administration for CID noted, 'A lot of the officers are very surprised, they are very shocked [...] I spent the first two weeks explaining what I was who I was, explaining' (volunteer 3). Another PSV, who explained his role as a 'data analyst', tended to obscure the fact that he was a volunteer to avoid other actions in the organisation questioning his role:

A lot of the officers don't know because my boss said 'don't put it on the email that you are a volunteer', which I don't do, it says 'data analyst' [...] They don't realize that volunteers like me do this work (volunteer 2)

More specifically, there can be confusion about what information PSVs can and cannot have access to. In the context that many areas of police business involves access to sensitive information about victims, offenders and the progression of criminal investigations, one police manager noted that salaried staff question 'what they are allowed to see, what can't they see' (manager 6). There can also be confusion about the boundaries of the PSV role. The hours worked by PSVs is structured more by their inclination rather than the requirements of the organisation and can be erratic:

I have had cases where I have had to say to officers sorry I can't do this today you will have to wait until tomorrow because I am finishing for the day .... It might be midday and they say well aren't you paid to work and I say I am volunteer I am not working you have to wait. We have had instances of that where people assume that you get paid (volunteer 2)

\section{The coordination, management and supervision of Police Support Volunteers (PSVs)}

As Bayley and Shearing (1996) note the increasing use of civilians in police work has important implications for the management and organization of constabularies. Indeed, given that PSVs conduct activities across the spectrum of police work and represent constabularies in wide ranging ways the ways that PSVs are coordinated, managed and supervised deserve consideration, let us consider these themes now. 
It is generally acknowledged that a paid volunteer manager or coordinator is essential to facilitate the development of successful volunteer programmes within public (and other) sector organisations (Brudney, 1999; Rochester et al, 2010). The PSV programme within this constabulary was coordinated by a small team at the time that the research was conducted. This team oversaw the generation of new PSV placements; managed recruitment and induction processes; provided support for supervisors; organised reward ceremonies and other formal and informal events for volunteers; produced and distributed a magazine aimed at highlighting their achievements; and, communicated with PSVs, handled their queries and provided additional support. The team, seen as highly committed, was admired and much valued by participants in the study who felt their activities and support were essential to the operation of the PSV programme:

[named individual] is such a good manager. She's great. They have these awards in the year. So that's good. There is big recognition of people and what they achieve (Volunteer 7)

However, the central team was not responsible for the day-to-day management and supervision of PSVs, which was devolved to the local teams who deployed them. It is acknowledged that volunteers should be managed and supported by the organisations that retain them and indeed for some commentators there is an obligation for organisations to do so (Rochester et al, 2010). This constabulary issues guidelines to local managers, guidelines which are similar to those provided by other constabularies (Wilkins, 2008). They state that PSVs should be trained, well-integrated into their team, should receive feedback on their performance and have an annual review. However, there is variation regarding whether guidelines are applied. Certainly, not all PSVs receive training. One manager explained:

If they are doing admin upstairs then yes, they get the training. But it doesn't necessarily extend. It's expensive if they are going to do just one day a week (manager 2).

It is not always possible to offer training for those who need it. As the quote above indicates, training incurs costs which needs to be balanced against the nature of the role being performed, the number of hours the PSV works for and acknowledgement that they may not be retained by the organisation for long. Even where it is agreed that a PSV needs training it 
might be time-consuming to arrange. One problem is that PSVs work flexible and limited hours which may or may not correspond with training course schedules. One PSV noted: 'yes, it was like picking through a minefield but yes eventually I did get bits and bobs of training' (Volunteer 7).

Typically there is limited formal oversight of the activities and outputs of PSVs. One manager explained:

Do you know, they don't require that much from us because you know they come in and do their job and it they have any queries they will call us or come and find us. But other than that they are sort of independent (manager 2)

As we have seen, some PSVs are geographically and temporally located away from the gaze of salaried employees. Some volunteers work at home, others work remotely in the community and yet others work in the evenings and at the weekends. These arrangements suit many PSVs who are in full time employment but they are times when regular officers and other salaried staff are less likely to be available to oversee their activities. Accordingly, for some the supervision of volunteers involves an occasional 'check in', sometimes by email or 'phone. This PSV illustrates:

He does 7am to 3pm. I certainly don't start that early but I sometimes catch him in the afternoon. But he's extremely busy. We'll touch base once or twice a week I'd say. I often go in at the weekend to be honest. Its quieter. I can get a PC. I might do 4 hours on a Sunday just to catch up on email (Volunteer 7)

The volunteer might not receive a great deal of feedback on their performance:

Very little feedback, to be honest. A lot of work, very little feedback [...] very, very frustrating [...] its only that, you know, but you know we had to prepare a big report but, you know, there is not a lot coming back the other way (volunteer 6)

Potentially, there are a number of implications both for the volunteer and the organisation. The volunteer might not feel that their contribution is valued. That volunteers need feedback to help ensure that they feel valued and so are retained is a theme clear in the wider literature regarding the management of volunteers (Wilson and Pimm, 1996; Rochester et al, 2010), a 
theme picked up by a number of participants in this study. One PSV noted 'unless managers give positive feedback they will feel not wanted and fade away' (volunteer 5). It also raises questions about how the work of volunteers is scrutinised, developed and improved. This brings us to matters about the quality of the work conducted by PSV. Poor performance was generally not thought to be a problem by those participating in this study. Participants tended to agree that on the whole volunteers were intrinsically motivated and that there would be little point in volunteering if you did not intend to contribute. One PSV noted, 'you would be a bit of a fool to volunteer if you didn't enjoy it, you would vote with your feet' (Volunteer 5). Even so, reliability did feature in the observations of those who participated in this study, as this manager indicates:

The biggest issue is that you can't hold them accountable because there is no authority. Some of the younger members, they give last minute notice because they have an exam. They just wouldn't turn up. It was about getting them to be accountable. That is the difference between paid staff and volunteers (manager 1)

As the quote suggests, the police organisation is somewhat powerless in the face of unreliability. Much of this comes down to the informal position of volunteers and the nature of the authority that the organisation holds over them. The manager previously quoted concluded that for paid staff 'if you don't turn up, if you go [Absent Without Leave], there are policies and procedures' but 'if you are a volunteer and you don't turn up there is not much you can do' (manager 1). Faith is placed in any problems being resolved locally and informally. Whilst guidance suggests that complaints about the performance, conduct or demeanour of a PSV need to be dealt with transparently, quickly and effectively to protect other volunteers, other actors in the organisation and the reputation of constabularies, it also reinforces the point that standard discipline and grievance procedures should not apply to volunteers. Reflecting on his experience with dealing with unmotivated PSVs, this manager explained that:

Mostly it's an adult conversation. You're not doing what we want. It's an adult conversation. Please hand in your badge (manager 6)

In more serious cases of misconduct guidance indicates that an appointment could be proactively terminated. However, it seems that it is more usual for PSVs who are 
unmotivated or performing under par to just 'drift off' (manager 6). It might be becoming clear that the processes of coordinating, managing and supervising volunteers within constabularies - as in other public sector organisations - are not straightforward ones. This section concludes with a consideration of some of the challenges.

Establishing processes through which to regulate PSVs, to manage their output and to support them may prove to be a primary challenge for contemporary constabularies. There is something of a tension when considering the matter of the regulation of PSVs. It is their informal status that enables constabularies to recruit volunteers relatively easily and at a relatively low cost and so from which many of the mooted benefits of utilizing them are assumed to flow. To formalise the relationship between volunteers and the organisations that deploy them risks undermining these proffered advantages. Indeed, formal processes risk altering the 'contractual' nature of the relationship between volunteers and the host organisation (Wilson and Pimm, 1996; Brudney, 1999; Wilson, 2000; Restall, 2005; Rochester et al 2010). However, managers will have to find ways to motivate volunteers to achieve certain outputs in lieu of pay and formal management processes. One manager noted 'You can't apply same set of rules to unpaid and paid staff but the issue is how you balance that with ensuring tasks are done' (manager 5). Such is the nature of the rank structure that some who manage PSVs assume that you can issue orders or instructions to PSVs, widely understood to be unacceptable practice within the management of volunteers (Wilson and Pimm, 1996; Wilson, 2000). Indeed, one PSV argued that 'you cannot express the attitude 'I am the boss just do it' you need to 'enthuse, support and encourage volunteers' (volunteer 12).

Compounding this, a 'one size fits all' is unlikely to be appropriate for the management of PSVs. It is understood that the motivations and expectations of volunteers can be highly varied, even where they are working for the same organisation (Bussell and Forbes, 2002). Volunteers are motivated to participate for very different reasons, they anticipate different forms of 'reward' and they are prepared to work different numbers of hours. In managing volunteers understanding and responding to these varied motivations is important. PSVs are clearly differently motivated. However, speaking broadly participations tended to draw attention to two groups of PSVs: 'an older group near or who are retired and a younger group who are looking for roles in the service and not much between' (volunteer 4). Either to test 
the water to get relevant experience to put on a CV, that younger PSVs were motivated by future paid positions was clear:

I'd always wanted to be a detective! I was thinking I would go and see what it was like and maybe I would apply to be a police officer. I have decided to go into the civilian side of it. I have got into it to see if I like it (volunteer 9)

Older volunteers 'want to do their bit to help, to understand or to give something back' (manager 6) but nevertheless also have personal reasons for doing volunteering too:

I had always been interested in helping, if you like, but I always liked the office. Because I miss work but for various reasons it was not possible for me to go back to work. So I am looking to replace that I suppose (volunteer 7)

Volunteers are also willing and/or able to work very different numbers of hours. Balancing the work loads of PSVs can be problematic. Many PSVs are enthusiastic, which ironically can generate problems. On the one hand, furnishing eager PSVs with sufficient work can be difficult. 'You can drive volunteers away, they don't want to be twiddling their thumbs' stated one manager (manager 6). On the other hand, eager volunteers might become overburdened. Guidance states that volunteers should work no more than forty hours a month. This reflects the doctrine - oft-stated in volunteer management literature - that that if a volunteer was indispensable it indicates that a permanent and salaried position is needed. Something acknowledged by participants in this study. One manager stated 'If the business of the unit would collapse if the volunteer left it indicates it is not for the volunteer - the volunteers should not be central to but adding to' (manager 3). Data obtained by Unison (2014) indicate that PSVs in this constabulary work on average about 22 hours a month clearly within the recommended range. However, there is variance. One participant stated that he did a six or seven hour day most days: 'I can't finish it all in one day' he explained (volunteer 2). Effective volunteer management requires that managers understand the benefits that individual volunteers expect to reap in order to tailor support towards these specific needs (Wilson and Pimm, 1996; Brudney, 1999; Rochester et al, 2010).

\section{The integration of Police Support Volunteers (PSVs) into constabularies}


Like most families, the policing family is not always a harmonious one. It is one riven with jealousies, enmity, competition, conflict and lack of mutual respect and common goals (Stenning, 2009: 23). Certainly, whilst PSVs are diffused throughout this constabulary, there are questions about the extent to which they are integrated into the organisation and accepted by other actors within, themes discussed in the following sections.

Whether PSVs are accepted by those with whom they work and the others within the organisation seems to vary. Certainly some PSVs feel well integrated into their teams, accepted by them and valued: 'people are always very grateful [my manager] says don't ever leave!' (volunteer 2). Points reflected by managers: 'they are part of the team and I get annoyed with people who don't think so' (manager 1). However, as the quote suggests, some in the organisation view PSVs sceptically. Scepticism can be generated by their novelty, feeling that they are temporary, their amateur status and 'threat' to paid positions. One volunteer noted:

Well I am lucky here because my neighbourhood officers are lovey and they know where the coffee is! It does vary, generally its good, but it does vary. What I have heard, where they are working at a desk, they are ignored. That has happened, and I can remember it, when you have a temporary member of staff in 'they are only temps' (volunteer 1)

One police manager likened scepticism of PSVs to early scepticism of PCSOs, uniformed axillary staff who were introduced to the police family at the turn of the century. Born of a lack of clarity about their position, limited training and poor supervision PCSOs, this manager explained, experienced a degree of estrangement from the police family (see also Kempa and Johnston, 2005; Johnston, 2005; 2007; O’Neill, 2014a, b). Whilst there is still some resistance to PCSOs, officers who have experienced first-hand what benefits they can bring to the organisation tend to support them (O’Neill, 2014b: 26). Similar points have been made about the relationship between special and regular officers. There is a volume of work which points to a troubled history of relations between special and regular officers (Seth, 1961; Leon, 1991; Mirrlees-Black and Bryon, 1994; Bullock, 2014; Bullock and Leeney, 2014). However, there is complexity and many special constables report positive relations with regular officers, especially where they work closely with them (Bullock and Leeney, 2014). In this vein, participants in this study generally felt that those who worked closely 
with them valued PSVs. 'Those who had used volunteers would use them again and again and again', noted one manager (manager 6). Reflecting on whether volunteers were assimilated into his team one volunteer stated 'they seem to be accepted but then they have been there for a while' (volunteer 6). The implication is that as regular police staff became used to working with them they would gradually become assimilated. Indeed, some interviewees suggested that constabularies should work to expedite this process through raising awareness:

I think we need to get more of a message out there. Police officers or managers are probably less likely to use volunteers than police staff members. That might be a generalization. But I think we could do more to drive out what volunteers do what options there are. I am not sure other people know what volunteers can do (manager 1)

However, arguing that such promotion would function to raise suspicion and anxieties amongst salaried staff, others disagreed. This point links to the extent to which salaried staff view PSVs as a threat to job security, a matter to which we now turn.

Threat to job security is a very clear reason why there might be resistance to the introduction of PSVs. Indeed, the nature of the relationship between volunteers and new actors within constabularies is likely to be shaped in part by the economic and political context of the day. Certainly, regular officers have perceived special constables to be a threat to any improvements in their pay and conditions and to the availability of paid overtime (Seth, 1961; Leon, 1991; Mirrlees-Black and Bryon, 1994; Gaston and Alexander, 2001). More broadly, officers may well resent the use of what they see as a cheaper alternative, a theme that has endured. Seth (1961: 187) provides the example of a letter to police review published $8^{\text {th }}$ April 1932 which stated:

In the minds of certain would-be economists the special constables are looked upon as a cheap and inexpensive auxiliary Force whose services as police officers are to be utilised wherever possible so that the Regular Police may be maintained at minimum strength. It is not surprising that on this view of the matter the Specials should not always be regarding with great favour by the Regular Police in the long run. 
Some thirty years later, Leon (1991) drew attention to the hostile reaction of the Police Federation, which represents rank and file police officers in England and Wales, to the suggestion that special constables might be used to fill gaps in provision created by resource constraints. Given that until relatively recently the number of PSVs has been small and the areas into which they have been deployed limited, it seems that few questions were asked about whether the deployment of PSVs had implications for salaried staff. Clearly this landscape has shifted. PSVs are being widely deployed at a time when constabularies are facing deep cuts to their budgets and accordingly at a time when positions are being lost and some salaried staff are facing redundancy. It would be surprising if there was not cynicism regarding the rationale for developing the role of the volunteer in this context. Indeed, the risk that the promotion of PSVs at the current time would be seen as job substitution was ever present in accounts of participants in this study. One volunteer explains.

The other thing is as well is that initially some people think 'you are taking someone's job'. There is always a risk of that. That can be difficult. That is why I am careful about what I will and won't do. If I think that it is a police officer's responsibility, I will say 'I don't think I should be doing this' (volunteer 4)

\section{Discussion and conclusion}

Whilst PSVs programmes have become established within constabularies and the numbers of PSVs have multiplied we know little about the ways that they are integrated into police organisations or the implications for the provision of effective policing services. This article sought to modestly add to our knowledge of the development of PSV programmes and the deployment of PSVs in contemporary constabularies focusing on the roles that PSVs play, their management and supervision and the nature of their integration into the organisation. In so doing it sought to extend our understanding of the pluralisation of policing in the context that research on volunteers is limited. In this final section the findings of this article are considered in light of the frameworks of plural policing. Within a differentiated patchwork of paid and unpaid, sworn and unsworn actors, key concerns for scholars of plural policing has been the implications for effectiveness, coordination and integration along with matters to do with regulation and governance. 
There has been recognition that the policing landscape is characterised by an ever-growing variety of state and non-state providers and 'that the responsibility for policing provision in liberal democratic societies is now in practice shared between a growing plethora of governmental and non-governmental providers' (Stenning, 2009: 21). Whilst much focus has been on the privatisation of public policing, this article has shed light on how volunteers are encroaching into spaces once occupied by paid agents within police organisations. This has to be understood within the context of a wider political project that seeks to reconfigure the relationship between the state and the citizen. Fundamentally this project is undermining the expectation that the state - or agents of the state - will provide services to citizens. Instead, the expectation is that citizens will play a role in the provision of these services. Indeed, this article has illustrated that volunteers are a growing component of the mixed economy of policing. This goes beyond traditional understanding of how constabularies co-produce crime control with citizens. Conventional mechanisms of co-production - say via Neighbourhood Watch programmes and forms of consultation - keeps citizens more or less at arm's length. In contrast, PSV programmes bring citizens to the heart of constabularies. PSVs resemble officers and staff in terms of appearance and the tasks that they perform. They are playing wide ranging roles that go well to the heart of what is typically understood as 'front line' policing and some are occupying roles once filled by paid staff. This starts to blur - literally and symbolically - the boundaries between paid officers and staff and volunteers. Indeed, the mixed economy of policing is perhaps best understood as an 'interplay' between state and non-state actors (Crawford, 2008a; Stenning, 2009). Indeed, it may be increasingly the case that the enactment of crime control - even under the umbrella of the public police - needs to be understood as the outcome of the interplay between paid and non-paid actors. However, this blurring is not without certain implications, to which we now turn.

Pluralizing the sources of policing affects quantity and quality (Bayley and Shearing, 1996). In respect to the former, as a branch of the extended police family PSVs are in a minority but with some 9,000 on the books in early 2014 (Unison, 2014) they are clearly adding strength. In respect to the latter, if furnished in furtherance of public safety the actions of the various actors that make up contemporary constabularies might be expected to add up to more than the sum of its parts (Crawford, 2008a). However, we do not know what impact they are having on the ability of constabularies to meet organisational aims. Whilst it is generally accepted that public sector organisations should evaluate the impact of their volunteer 
programmes (Brudney, 1999), there is little evidence that this is happening in respect to PSV programmes (Unison, 2014).

In considering whether the deployment of PSVs is likely to improve public safety, inevitably much will depend on how they are coordinated, deployed and supported. There has been recognition that coordination of actors within the mixed economy of policing has been poor and that the field has developed unevenly (Crawford, 2008a). Similar themes are evident within the realm of PSV programmes. There has been limited strategic oversight at the central level (Wilkins, 2008; NPIA, 2010; Bullock, 2014) and local programmes are not always overseen by a coordinator (Wilkins, 2008). Indeed, whilst the activities of PSVs in the constabulary that was the focus of the present study were coordinated by a much respected team, it was disbanded after the research was conducted, presumably because of budget constraints. There are also questions about how PSVs are deployed and the nature of the contribution they make. PSVs can be characterised as a fluid resource over which constabularies have little authority. Constabularies cannot require PSVs to perform certain duties and must allow them autonomy to determine the hours they work. In turn, PSVs are more or less dependable, they are prepared to work more or less hours and are retained for very different periods of time. This may influence whether PSVs affect the ability of constabularies to provide a consistent and coherent service. Whilst many PSVs are no doubt contributing, this article has drawn attention to poor harmonisation between PSVs and other actors and teams within the organisation and confusion about their roles and position in the organisation. In addition, some PSVs and indeed some teams of PSVs are working autonomously from other actors in the organisation. All of this is potentially troubling not least because it raises questions about the quality of their contribution and it raises the risk of duplication and poor coordination. At the very least this indicates that attention needs to be given to how PSVs are organised and their activities harmonised.

If members of the extended police family are 'to facilitate police sovereignty over security governance, they must be integrated successfully with their newly adopted 'family' members' (Kempa and Johnston, 2005: 183). Integrating new members into the police family has not always been straightforward as evidenced by the experiences of PSCOs (Kempa and Johnston, 2005; O’Neill, 2014a,b) and special constables (Seth, 1991; Leon, 1991; MirrleesBlack and Bryon, 1994; Bullock, 2014; Bullock and Leeney, 2014). Born of their novelty, their amateur status and the potential implications for paid positions, it is far from clear that PSVs are integrated into the wider police family at the time of writing. Indeed, writing at a 
time of state contraction a major risk to the effective deployment of PSV programmes is scepticism from other actors in the police family. Rationalising reorganisation and retrenchment with recruiting ever more PSVs may well be a problem and is a matter that needs sensitive handling. Gravelle and Roberts (2009) noted that the deployment of several hundred PSVs in one English constabulary was put on hold in the context of union concerns about the implications for paid positions. Indeed, in the context of an ongoing force reorganisation, the recruitment of volunteers in this constabulary was (temporarily) on hold at the time of writing. The anxiety of salaried staff formally acknowledged.

Regulation - especially as it relates to the market for private security and the privatisation of functions traditionally allied to the public police - has been a dominant theme within the literature on pluralisation (Crawford and Lister, 2004 a,b; Stenning, 2000; 2009). Whilst it is far from the case that new additions to the extended policing family are unregulated (Stenning, 2000; 2009), pluralisation undoubtedly 'interrupts' our understanding of established patterns of regulation (Loader, 2000). The reason for this is that the indirect (e.g. legal, political, administrative and financial) and direct (e.g. local consultation arrangements) forms of accountability that oversee the public police do not typically apply or are weakly applied (Crawford and Lister, 2004b). Indeed, whilst there has been recognition that the enactment of policing is characterised by an ever-growing variety of state and non-state policing providers the implications for the provision of public policing and effective governance and accountability of policing have not as yet been sufficiently acknowledged and explored (Stenning, 2009; Loader, 2000). This is something that certainly applies to PSVs and other volunteers within the policing family.

Unlike the actors who provide policing functions within private organisations, PSVs are clearly situated firmly within the public police. However, they are also they are also removed from the processes that typically regulate actors therein. This article has drawn attention to how the position of the PSV is an informal one. The mechanisms through which PSVs are regulated are fragile. Where performance bedevils organisational expectations, leeway will typically be shown and formal disciplinary action is avoided. The police organisation has limited authority over the PSV, inevitably leading to questions about their regulation.

Recognising that PSV represent them in wide ranging ways and in light of literature which promotes 'best practice' in volunteer management, guidelines which seek to structure the 
recruitment and management of PSVs have been produced by constabularies. However, in and of themselves 'light touch' this article has drawn attention to how these are applied more or less proactively. Throughout this article, it has been emphasised that constabularies should not be looking to establish systems of management that simply mirror those of salaried staff. Instead, constabularies will have to develop new ways to support volunteers and will need to work flexibly to understand the varied motivations and expectations of volunteers and tailor the processes and practices of oversight, development and review to them. Whilst constabularies have recognised that the traditional quasi-military management model, based on ranks and a clear chains of command, may not accommodate the requirements of modern policing and has been talking about the value of participative and collegial management (Bayley and Shearing, 1996: 591), constabularies will have to think carefully about the introduction of forms of management suitable for volunteers.

All of this links to matters of accountability. Systems of oversight are one way through which actors in the extended police family are held to account (Manning, 2013), systems minimally developed and applied to volunteers as has been stressed. However, systems of redress are also important. At present, in the event of a complaint about the demeanour or conduct of a volunteer or the quality of the service they provide there will be little recompense for a citizen or indeed for the constabularies that volunteers represent (Fredericksen and Levin, 2004). Since PSVs do not sport coercive powers and cannot directly enforce the laws of the land, the risk posed might appear to be minimal. However, as has been demonstrated, the contours of the role are poorly defined and there is blurring between salaried and non-salaried positions. They also represent constabularies in wide ranging ways. The informal status of volunteers affords constabularies benefits - especially in respect to cost - yet there is no reason to assume that citizens will accept inferior levels of service, poor conduct or view volunteers to be any less accountable than those formally engaged by the organisation (Fredericksen and Levin, 2004). Failure to adopt systems whereby actors within police organisation can be held to account risks their legitimacy. Whilst being careful not to overstate the risk, the establishment of effective mechanisms of accountability are essential for promoting the legitimacy of constabularies and to the achievement of their wider aspirations including generating trust, confidence and cooperation of citizens in the execution of crime control (Tyler, 1990; Sunshine and Tyler, 2003; Hough et al, 2010).

\section{Concluding comment}


In the context of a governmental project aimed at recalibrating the relationship between the state and citizens, significant cut backs in expenditure and never-ending demand for security from citizens, it is easy to see why constabularies have pursued the labour of PSVs. Volunteering in the police service is hardly new - Special Constables have been part of the landscape since (at least) the 1831 Special Constables Act - but matters of their deployment take on significance in a political landscape where the their role is being widely promoted, where their numbers have grown quickly and the functions they provide diversified. This is not a position unique to constabularies. However, the 'unique' position held by actors within constabularies - who hold significant real and symbolic power - demands that proper attention is paid to matters of regulation and accountability. To fail to do so risks legitimacy. Through forming a 'bridge' between officers and citizens, PSV Programmes have been presented as a way of fostering mutual knowledge and understanding between citizens, communities and constabularies and in so doing improving their legitimacy and effectiveness (NPIA, 2008; Neuberger, 2009).Whether these aspirations can be realised is at best unclear. We do not know what impact they are having on the ability of constabularies to meet organisational aims. The proliferation of volunteers into wide-ranging roles has occurred with little debate or scrutiny. That there are roles within constabularies that are suitable for volunteer, that most PSVs will be well-meaning and that PSV programmes may well bring benefits to the organisations that retain them cannot be denied. However, the impact of deploying PSVs on the public interest warrants empirical examination and the best ways of managing and supporting them given the wide-ranging roles that they appear to be playing needs consideration at the central and local levels.

\section{References}

Bayley, D. and Shearing, C. (1996) The Future of Policing, Law and Society Review 30 (3) 585-606.

Bullock, K. (2014) Citizens, Community and Crime Control. Basingstoke: Palgrave Macmillan.

Bullock, K and Leeney, D (2014) On matters of balance: an examination of the deployment, motivation and management of the Special Constabulary, Policing and Society:

An International Journal of Research and Policy, DOI: 10.1080/10439463.2014.949713 
Brudney, J. (1999) The Effective Use of Volunteers: Best Practices for the Public Sector, Law and Contemporary Problems, 62 (4) 219-255

Bussell, H. and Forbes, D. (2002) 'Understanding the volunteer market: The what, where, who and why of volunteering', International Journal of Nonprofit and Voluntary Sector Marketing, 7 (3) 244-257

Cabinet Office (2010) The Coalition: Our Programme for Government. London: Cabinet Office. Available at: https://www.gov.uk/government/publications/the-coalition-documentation (14/3/14)

The Conservative Party (2010) Big Society, Not Big Government: Building a Big Society London: The Conservative Party http://www.conservatives.com/News/News_stories/2010/05/Plans_for_building_the_Big_Soc iety_launched.aspx $(12 / 5 / 14)$

Crawford, A (1999) The Local Governance of Crime: Appeals to community and partnership. Oxford: OPU.

Crawford, A. (2008a) Plural Policing, in T. Newburn and P. Neyroud (eds) Dictionary of Policinf. Cullompton: Willan

Crawford, A. (2008b) Plural Policing in the UK: Policing Beyond the Police, in T. Newburn (ed) A Handbook of Policing. Cullompton: Willan.

Crawford, A. (2013) 'The Police, Policing and the Future of the "Extended Policing Family", in J. Brown (ed.) The Future of Policing Abingdon: Routledge

Crawford, A. and Lister, S. (2004a) The patchwork shape of reassurance policing in England and Wales: Integrated local security quilts or frayed, fragmented and fragile tangled webs? Policing: An International Journal of Police Strategies \& Management 27 (3) 413-430 
Crawford, A. and Lister, S. (2004b) The extended policing family: Visible patrols in residential areas. York: Joseph Rowntree Foundation.

Emsley, C. (2011) Crime and Society in Twentieth-Century England. Harlow:

Longman/Pearson.

Etzioni, A. (1995) The Spirit of Community. Rights responsibilities and the communitarian agenda, London: Fontana Press.

Fredericksen, P. and Levin, D. (2004) Accountability and the Use of Volunteer Officers in Public Safety, Public Performance \& Management Review 27 (4) 118-143

Hough, M., Jackson, J. Bradford, B. Myhill, A. and Quinton, P. (2010) Procedural Justice, Trust, and Institutional Legitimacy, Policing, 4(3) 203-210

Garland, D. (1996) The Limits of the Soverign State. British Journal of Criminology 36 (4) 445-471.

Gaston, K. and Alexander, J. (2001) 'Effective organisation and management of public sector volunteer workers: Police Special constables', The International Journal of Public Sector Management 14 (1) 59-74.

Giddens, A. (1998) The Third Way: The Renewal of Social Democracy. Cambridge: Polity Press.

Gravelle, J. and Rogers, C. (2009) The Economy of Policing: The Impact of the Volunteer, Policing 4 (1) 56-63.

HMIC (2011) Demanding Times: The front line and police visibility. London: HMIC. Available at: http://www.hmic.gov.uk/media/demanding-times-062011.pdf (14/3/14)

HMIC (2013) Policing in Austerity: Rising to the Challenge. London: HMIC.

http://www.justiceinspectorates.gov.uk/hmic/media/policing-in-austerity-rising-to-thechallenge.pdf $(14 / 3 / 14)$ 
HMIC (2014) Policing in Austerity: Meeting the Challenge. London: HMIC.

http://www.justiceinspectorates.gov.uk/hmic/wp-content/uploads/policing-in-austeritymeeting-the-challenge.pdf $(14 / 3 / 14)$

Home Office (2001) ‘Policing a New Century: A Blueprint for Reform'. London: Home Office.

https://www.gov.uk/government/uploads/system/uploads/attachment_data/file/250905/policin g_survey.pdf $(14 / 3 / 14)$

Home Office (2004). Building Communities, Beating Crime: a Better Police Service for the 21st Century, CM 6360. Home Office: London.

http://www.archive2.official-documents.co.uk/document/cm63/6360/6360.pdf (14/3/14)

Johnston, L (2005) From 'community' to 'neighbourhood' policing: police community support officers and the 'police extended family' in London, Journal of Community \& Applied Social Psychology 15 (3) 241-254

Johnston, L. (2007) Keeping the Family Together'. Police Community Support Officers and the 'Police Extended Family' in London, Policing and Society: An International Journal of Research and Policy 17 (2) 119-140.

Kempa, M. and Johnston, L. (2005) Challenges and Prospects for the Development of Inclusive Plural Policing in Britain: Overcoming Political and Conceptual Obstacles, Australian \& New Zealand Journal of Criminology 38 (2) 181-191

Laycock, and Tilley, N. (1995) Policing and Neighbourhood Watch: Strategic Issues. Police Research Group Crime Detection and Prevention Series Paper no. 60. London: Home Office. Available at http://www.popcenter.org/problems/credit_card_fraud/PDFs/Laycock_Tilley_1995.pdf

Leon, C. (1991) Special constables: An Historical and Contemporary Survey, unpublished Phd. Bath: University of Bath. 
Loader, I., (1997) Policing the social: Questions of symbolic power. British Journal of Sociology, 48(1) 1-18

Loader, I. (2000) Plural Policing and Democratic Governance. Social and Legal Studies, 9 (3) $323-45$.

Manning, P. (2013) Policing: Privatising and Changes in the Policing Web, in J. Brown (ed) The Future of Policing. Abingdon: Routledge.

Mirrlees-Black, C. and Byron, C. (1994), Special Consideration: Issues for the Management and Organisation of the Volunteer Police, Home Office Research and Planning Unit paper 88, London: Home Office.

Neuberger, J. (2009) Volunteering across the criminal justice system: Baroness Neuberger's review as the Government's Volunteering Champion. London: Home Office. Available at: http://www.oneeastmidlands.org.uk/sites/default/files/library/volunteers\%20in\%20cjs.pdf $(14 / 3 / 14)$

NPIA (2008) Special Constabulary National Implementation Advice. London: NPIA Available at: http://www.npia.police.uk/en/docs/Imp_Strategy_updated.pdf (12/4/14)

O’Malley, P. and Palmer, D. (1996) Post-Keynesian policing. Economy and Society, 25(2) $137-155$

O' Neill, M. (2014a) Ripe for the chop or the public face of policing?: PCSOs and Neighbourhood Policing in austerity, Policing: a Journal of Policy and Practice, 8 (3): 265273

O’Neill, M. (2014b) PCSOs as the Paraprofessionals of Policing: findings and recommendations from a research project. http://www.sipr.ac.uk/downloads/PCSO_project_report.pdf 
ONS (2013) Police workforce, England and Wales, 30 September 2013. London: ONS. Available at: https://www.gov.uk/government/publications/police-workforce-england-andwales-30-september-2013/police-workforce-england-and-wales-30-september-2013 $(12 / 4 / 2014)$

Parsons, J. (2008) Key Informant, in P. Lavrakas Encyclopedia of Survey Research Methods. Sage: London.

Putnam, R. (2000). Bowling alone: The collapse and revival of community in America. New York: Simon \& Schuster.

Reiner (2000) The Politics of the Police. Oxford: Oxford University Press.

Restall, M. (2005) Volunteers and the Law. Volunteers England: London. Available at: http://plantnetwork.org/wordpress/wp-content/uploads/9122/volunteers-and-the-law.pdf $\underline{(12 / 4 / 14)}$

Rochester, C., Ellis Paine, A. and Howlett, S. (2010) Volunteering and Society in the 21st Century, Palgrave Macmillan: Basingstoke.

Rose, N. and Miller, P, (1992) Political power beyond the State: Problematics of government. British Journal of Sociology, 43(2), pp. 173-205

Rosenbaum, D. (1987) The Theory and Research Behind Neighbourhood Watch: Is It a Sound Fear and Crime Reduction Strategy, Crime and Delinquency 35 (1) 105-134

Rowland, R. and Coupe, T. (2014) Patrol officers and public reassurance: a comparative evaluation of police officers, PCSOs, ACSOs and private security guards, Policing and Society 24 (3) 265-284

Seth, R. (1961) The Specials: The Story of the Special Constabulary. London: Victor Gollancz Ltd. 
Stenning, P. (2000) Powers and Accountability of Private Police, European Journal on Criminal Policy and Research 8 (3) 325-352

Stenning, P. (2009) Governance and Accountability in a Plural Policing Environment - the Story so Far, Policing 3 (1): 22-33.

Sunshine, J. and Tyler, T. (2004) The role of procedural justice and legitimacy in shaping public support for policing, Law and Society Review, 37 (3) 513-547.

Trojanowicz, R and Bucqueroux, B. (1990) Community Policing: A Contemporary Perspective. Cincinnati, OH: Anderson Publishing Ltd.

Tyler, T. (1990) Why people obey the law. Princeton: Princeton University Press.

Unison (2014) Home Guard of Police Support Volunteers to Fill in For Staff Cuts. London: Unison.

Whittle, J. (2014) The Rise of the Special Constabulary: are Forces Getting Value for Money from their Voluntary Officers? An Empirical Study in Avon and Somerset Police, Police Journal: Theory, Practice and Principles 87 (1) 29-40

Wilkins, T. (2008) 2008 PSV (PSV) Questionnaire. London: College of Policing. Available at:

http://www.college.police.uk/en/docs/2008_Final_Questionnaire_analysis.pdf (12/4/14)

Wilson, J. (2000) Volunteering, Annual Review of Sociology, 26 215-240

Wilson, A. and Pimm, G. (1996) The Tyranny of the Volunteer: The Care and Feeding of Voluntary Workforces. Management Decision, 34 (4) 24-40 